\title{
ANALISIS KEEFEKTIFAN KALIMAT DALAM SKRIPSI MAHASISWA PRODI PENDIDIKAN UNIVERSITAS MALIKUSSALEH
}

\author{
oleh \\ Nurmaya Sari, Syahriandi ${ }^{*}$, Rani Ardesi Pratiwi \\ *Dosen Program Studi Pendidikan Bahasa Indonesia, FT Universitas Malikussaleh \\ surel: syahriandi@unimal.ac.id
}

\begin{abstract}
ABSTRAK
Penelitian ini bertujuan mendeskripsikan keefektifan kalimat dalam skripsi mahasiswa Prodi Pendidikan Universitas Malikussaleh. Jenis penelitian dalam penelitian ini menggunakan jenis penelitian kualitatif dengan dan pendekatan deskriptif. Penggunaan pendekatan ini bertujuan untuk mendeskripsikan data selengkap-lengkapnya secara jelas dan lugas. Data penelitian ini adalah kalimat tidak efektif yang terdapat dalam skripsi mahasiswa Prodi Pendidikan Universitas Malikussaleh. Sumber data dalam penelitian ini adalah skripsi mahasiswa Prodi Pendidikan Universitas Malikussaleh yang dicetak pada tahun 2019. Teknik analisis data pada penelitian ini menggunakan empat tahap, yaitu (1) mengumpulkan sampel dan mengidentifikasi kesalahan, (2) mengklasifikasi data, (3) mendeskripsikan kesalahan, dan (4) mengevaluasi dan menyimpulkan kesalahan. Hasil penelitian menunjukkan bahwa jumlah kalimat tidak efektif yang terdapat dalam skripsi mahasiswa Prodi Pendidikan Universitas Malikussaleh yang lulus pada tahun 2019 adalah 339 kalimat. Rincian pengklasifikasian kesalahan kalimat tersebut, yaitu kalimat tidak efektif yang disebabkan oleh kekeliruan bentukan bagian kalimat, kesalahan struktur pengungkapan dan kepaduan kalimat, dan kesalahan penggunaan kata meliputi pemborosan kata, penggunaan bahasa yang tidak tepat, dan penggunaan bahasa yang bermakna ambigu.
\end{abstract}

Kata Kunci: analisis, keefektifan kalimat, skripsi 


\section{PENDAHULUAN}

Pada dasarnya, penyusunan karya tulis ilmiah harus berlandaskan pada ciri keilmiahan suatu karya. Syahriandi (2019:183) menyebutkan bahwa terdapat beberapa ciri keilmiahan dalam karya tulis ilmiah, yaitu: a) isi kajiannya membahas pengetahuan ilmiah (bukan imajinasi), b) menggunakan metode dan cara berpikir ilmiah, c) format penulisannya mengikuti sistematika yang sudah ditetapkan (tergantung pada instansi tertentu), d) menggunakan bahasa ilmiah, yaitu lugas, logis, efisien, efektif, dan menarik. Sebuah karya tulis tidak dikategorikan ke dalam karya tulis ilmiah apabila salah satu ciri keilmiahan itu tidak terdapat dalam karya tulis tersebut. Biasanya, format penulisan suatu karya ilmiah mengikuti sistematika yang telah ditetapkan pada masing-masing instansi.

Penggunaan bahasa ilmiah dalam karya tulis (skripsi) merupakan salah satu ciri keilmiahan yang harus diterapkan. Bahasa ilmiah meliputi penggunaan ejaan, pemilihan kata (diksi) yang tepat, dan penggunaan kalimat yang efektif. Kunjana (dalam Zulmaliza, 2018:8) menyatakan bahwa kalimat efektif mampu menimbulkan kembali gagasan dan pikiran pada diri pendengar atau pembaca sehingga dapat menerima gagasan penulis secara utuh. Oleh karena itu, dalam penulisan skripsi haruslah menggunakan kalimat efektif supaya tidak terjadinya kesalahan penafsiran dan penalaran. Selain itu, kalimat yang digunakan dalam penyusunan skripsi adalah kalimat baku dan efektif karena skripsi merupakan salah satu karya tulis ilmiah yang harus memuat ciri-ciri keilmiahan suatu karya tulis. Namun, dalam skripsi mahasiswa prodi pendidikan masih terdapat beberapa kerancuan dan kesalahan dalam penulisan kalimat sehingga mengakibatkan terjadinya kesalahan penafsiran dan penalaran bagi pembaca.

Berikut ini beberapa kalimat dalam skripsi mahasiswa Prodi Pendidikan Universitas Malikussaleh yang menggunakan kalimat tidak efektif:

1) Bulan Juni peneliti menganalisis data dari hasil jawaban siswa yang terkumpul.

2) Menurut Gravemeijer (dalam Habib, 2017:268) mengatakan bahwa berdasarkan masalah konstekstual, siswa dituntun untuk menciptakan model of untuk model for.

3) Kedua faktor tersebut yang menyebabkan kemampuan berpikir kritis siswa rendah.

Kalimat (1) tidak efektif karena mengalami kesalahan bagian kalimat. Untuk memperbaiki kalimat tersebut, dapat dilakukan dengan menambahkan fungsi keterangan "pada" di awal kalimat, atau ditambahkan tanda koma (,) sebagai pemisah antara keterangan dan subjek.

1a) Pada bulan Juni, peneliti menganalisis data dari hasil jawaban siswa yang terkumpul.

1b) Bulan Juni, peneliti menganalisis data dari hasil jawaban siswa yang terkumpul.

Kalimat (2) tidak efektif karena unsur kalimat tidak lengkap atau tidak sepadan. Ketidaklengkapan unsur tersebut dapat dilihat dari penggunaan kata menurut dan mengatakan sebagai ungkapan pengantar kalimat. Selain itu, kalimat tersebut mengalami pleonasme pada kata bahwa dan berdasarkan.

Kesalahan lainnya pada kalimat (2) ada tidak adanya kesepadanan kalimat pada kata dituntun dan menciptakan. Kalimat tersebut dapat diperbaiki dengan menghilangkan kata menurut supaya fungsi predikat menjadi jelas, atau menambah kata ganti "ia" supaya fungsi subjek dan predikat menjadi jelas. Kesalahan pada penggunaan kata bahwa dan berdasarkan dapat diperbaiki dengan menghilangkan kata berdasarkan supaya tidak terjadinya pemborosan kata. Sementara itu, kesalahan kesepadanan kalimat dapat diperbaiki dengan menggunakan imbuhan yang sama sehingga menjadi menuntun dan menciptakan.

2a) Gravemeijer (dalam Habib, 2017:268) mengatakan bahwa masalah konstekstual menuntun siswa untuk menciptakan model of untuk model for. 2b) Menurut Gravemeijer (dalam Habib, 2017:268), ia mengatakan bahwa masalah konstekstual menuntun siswa untuk menciptakan model of untuk model for. 
Kalimat (3) tidak efektif karena tidak memiliki unsur predikat. Kalimat tersebut dapat diperbaiki dengan menghilangkan kata "yang" supaya unsur predikat menjadi jelas.

3a) Kedua faktor tersebut menyebabkan kemampuan berpikir kritis siswa rendah.

Berdasarkan pemaparan tersebut, peneliti merasa perlu untuk meneliti bentuk keefektifan kalimat dalam skripsi mahasiswa prodi pendidikan Universitas Malikussaleh dengan judul "Analisis Keefektifan Kalimat dalam Skripsi Mahasiswa Prodi Pendidikan Universitas Malikussaleh". Peneliti tertarik untuk melakukan penelitian tentang keefektifan kalimat didasari oleh beberapa hal, yaitu: (1) kalimat efektif merupakan ciri keilmiahan suatu karya, (2) peneliti mengamati bahwa masih ada skripsi Mahasiswa Prodi Pendidikan Universitas Malikussaleh yang menggunakan kalimat tidak efektif, (3) belum ada yang meneliti tentang keefektifan kalimat dalam skripsi Mahasiswa Prodi Pendidikan Universitas Malikussaleh, (4) keinginan peneliti untuk menganalisis dan mendeskripsikan bentuk keefektifan kalimat dalam skripsi Mahasiswa Prodi Pendidikan Universitas Malikussaleh. Adapun fokus penelitian ini adalah kalimat dalam skripsi skripsi mahasiswa Prodi Pendidikan Bahasa Indonesia, Prodi Pendidikan Matematika, Prodi Pendidikan Fisika, dan Prodi Pendidikan Kimia.

\section{LANDASAN TEORI \\ Hakikat Kalimat}

Kalimat merupakan salah satu objek kajian sintaksis. Kalimat adalah rangkaian kata yang berisi pikiran dan makna lengkap. Sasangka (2014:15) menyatakan bahwa kalimat adalah satuan bahasa terkecil yang dapat mengungkapkan pikiran utuh dan informasi yang lengkap. Setiap tuturan dalam kalimat dapat mengungkapkan suatu informasi yang jelas. Akan tetapi, kata tersebut tidak termasuk kalimat apabila suatu susunan kata tidak memiliki pikiran yang utuh.

Kalimat dalam ragam resmi harus memiliki sebuah subjek (S) dan predikat (P). Namun, jika tidak memiliki kedua unsur tersebut, pernyataan itu bukanlah kalimat melainkan hanya sebuah frasa. Itulah perbedaan antara frasa dan kalimat. Syahriandi (2018:13) menyatakan bahwa kalimat merupakan kesatuan bahwa yang mengandung pikiran dan makna serta memiliki unsur relatif lengkap, yaitu sekurang-kurangnya memiliki predikat $(\mathrm{P})$ dan subjek (S) yang diawali dengan huruf kapital dan diakhiri dengan kesenyapan final.

Kalimat merupakan susunan kata yang dapat berdiri sendiri dan mengikuti kaidah kebahasaan serta dapat mengungkapkan gagasan secara tepat. Kridalaksana (dalam Zulmaliza (2018:7) menyatakan bahwa kalimat sebagai satuan bahasa yang berdiri sendiri dan mempunyai pola intonasi final. Penyusunan kalimat tidak terlepas dari kaidah kebahasaan, dalam susunan kalimat sekurang-kurangnya harus memiliki subjek dan predikat yang diawali dengan kesenyapan dan diakhiri dengan intonasi final.

Kalimat dalam wujud lisan diucapkan dengan intonasi naik turun dan keras lembut disela jeda, serta diakhiri dengan intonasi akhir berupa intonasi final, yaitu intonasi berita, intonasi tanya, intonasi perintah, dan intonasi seru. Sementara itu, dalam wujud tulisan kalimat dimulai dengan huruf kapital dan diakhiri dengan lambang intonasi final, yaitu tanda titik (.), tanda tanya (?) dan tanda seru (!).

Berdasarkan pendapat para ahli, dapat disimpulkan bahwa kalimat adalah satuan bahasa terkecil berupa ujaran atau teks yang mengungkapkan suatu informasi secara utuh. Kalimat merupakan susunan kata yang diawali dengan kesenyapan dan diakhiri dengan intonasi final. Selain itu, unsur fungsi sintaksis yang wajib ada dalam kalimat adalah subjek dan predikat, sedangkan unsur lainnya hanya sebagai unsur penunjang dalam sebuah kalimat.

\section{Syarat Kalimat dan Alat Pengetesnya}

Persyaratan pokok yang perlu diperhatikan dalam penentuan sebuah pernyataan berupa kalimat atau bukan adalah (a) adanya unsur predikat dan (b) permutasi unsur kalimat. Keduanya dapat dijadikan alat untuk mengetes sebuah pernyataan. Sofia (2017:40) menyatakan bahwa setiap kalimat dalam realisasinya sekurang-kurangnya memiliki predikat, sedangkan pernyataan (kelompok kata) yang tidak memiliki predikat disebut frasa. Untuk menentukan 
predikat sebuah kalimat dapat dilakukan pemeriksaan terhadap verba untaian kata bersangkutan.

\section{Fungsi dan Unsur-unsur Kalimat}

Kalimat terdiri dari beberapa unsur yaitu subjek, predikat, objek, pelengkap, dan keterangan. Sofia (2017:39) menyebutkan 5 unsur kalimat, yaitu subjek, predikat, objek, pelengkap, dan keterangan. Masing-masing unsur tersebut memiliki ciri-ciri tersendiri yang membedakannya antara unsur yang satu dengan unsur yang lainnya. Sama halnya dengan pendapat tersebut, Syahriandi (2018:13) menyatakan bahwa wujud fungsi sintaksis adalah subjek, predikat, objek, pelengkap, dan keterangan. Namun, tidak semua kalimat harus mengandung semua fungsi sintaksis tersebut, unsur sintaksis yang harus ada dalam setiap kalimat adalah subjek dan predikat.

\section{Pengertian Kalimat Efektif}

Kalimat efektif mampu menciptakan kesepahaman antara penulis dan pembaca sehingga tidak terjadinya kesalahan penalaran. Putrayasa (2010:35) menyatakan bahwa kalimat efektif merupakan kalimat yang mudah dipahami karena pernyataan yang disampaikan oleh penulis atau pembicara dapat diterima oleh pembaca ataupun pendengar. Selain itu, Sasangka (2014:54) menyatakan bahwa efektif bermakna "membawa pengaruh", artinya kalimat efektif dapat mempengaruhi pembaca serta dapat menyampaikan informasi kepada pembaca secara utuh, komunikatif, dan sesuai dengan kebahasaan yang berlaku. Kalimat efektif tidak hanya dibangun oleh struktur gramatikal, tetapi keefektifan kalimat dapat ditingkatkan melalui kemampuan menggunakan variasi pemilihan kata serta keragaman konstruksinya.

Kalimat efektif mencangkup keseluruhan dari kaidah bahasa, mulai dari tanda baca, ejaan, dan lain sebagainya. Atmazaki (dalam Kusmiyati, 2016:5) menyatakan bahwa kalimat efektif adalah kalimat yang tidak memerlukan banyak kosa kata, melainkan kata yang tersusun sesuai dengan pola kalimat yang benar menurut kaidah bahasa, sehingga dapat dipahami oleh pembaca secara tepat. Apabila terdapat kesalahan pada salah satu ciri kaidah kebahasaan, kalimat tersebut bukanlah kalimat efektif.

Salah satu faktor kebahasaan yang perlu diperhatikan dalam ragam komunikasi tulis adalah penggunaan kalimat efektif. Kalimat efektif menjadi peran penting dalam menyampaikan ide dan gagasan kepada pembaca. Sofia (2017:42) menyatakan bahwa kalimat efektif adalah kalimat yang sesuai dengan kaidah bahasa, sehingga apa yang disampaikan oleh penulis dapat diterima dan dipahami secara tepat oleh pembaca. Kalimat efektif adalah satuan bahasa yang secara tepat dapat mengungkapkan maksud penulis.

Jehamin (2019:45) menyatakan bahwa penyimpangan kalimat efektif yang sering terjadi adalah penyimpangan prinsip kehematan, kesepadanan, penggunaan konjungsi, penyimpangan prinsip kecermatan, dan kelogisan. Penyimpangan prinsip kehematan meliputi penggunaan kalimat yang memiliki makna yang sama. Penyimpangan prinsip kesepadanan struktur meliputi ketidakjelasan predikat dan penggunaan konjungsi yang kurang tepat. Penyimpangan penggunaan konjungsi meliputi penggunaan konjungsi antarkalimat. Penyimpangan prinsip kecermatan meliputi penggunaan tanda baca dan kesalahan penulisan ejaan.

\section{Ciri-ciri Kalimat Efektif}

Terdapat beberapa pendapat para ahli mengenai ciri-ciri kalimat efektif. Salah satunya adalah pendapat Parto (2018:247) menyebutkan ciri-ciri kalimat efektif, yaitu kesepadanan, keparalelan, kehematan, kecermatan, kepaduan, dan kelogisan. Sementara itu, Syahriandi (2019:139) membagikan ciri kalimat efektif dalam dua bagian, yaitu ketepatan struktur kalimat, dan ketepatan makna kalimat. Dalam penelitian ini, peneliti mengambil pendapat dari Syahriandi (2019) karena penjelasan ciri-ciri kalimat efektifnya lebih terperinci.

\section{Ketepatan Struktur Kalimat}

Kalimat efektif mempunyai struktur kalimat yang jelas. Struktur kalimat merupakan salah satu syarat keilmiahan suatu karya tulis. Syarat-syarat ketepatan struktur kalimat mencakup beberapa hal berikut ini, yaitu:

1) Ketepatan Bentukan bagian Kalimat

Dalam pemakaian bahasa, sering ditemukan bagian kalimat majemuk yang 
ditulis terpisah dari bagian kalimatnya, hal tersebut biasanya terjadi karena kekeliruan ketika menggunakan konjungsi. Febriantika (2016:19) menyatakan bahwa konjungsi adalah kata yang menghubungkan kata dengan kata dalam sebuah frasa atau menghubungkan klausa dengan klausa dalam sebuah kalimat disebut konjungsi intrakalimat.

Contoh:

(1) Kami datang terlambat. Sehingga kami tidak dapat mengikuti perkuliahan

Perbaikan kalimat ini dapat dilakukan dengan dua cara. Pertama, mengubah kalimat menjadi kalimat majemuk dengan menggunakan penghubung (konjungtor) sehingga, dan cara yang kedua adalah mengganti ungkapan penghubung intrakalimat (sehingga) menjadi ungkapan penghubung antarkalimat (oleh karena itu), seperti pada kalimat (1a) dan 1b) berikut.

(1a) Kami datang terlambat. Oleh karena itu, kami tidak dapat mengikuti perkuliahan.

(1b) Kami datang terlambat sehingga kami tidak dapat mengikuti perkuliahan.

2) Kejelasan penggunaan unsur/fungsi kalimat

Kejelasan penggunaan unsur/fungsi kalimat dapat juga dikatakan dengan kesepananan struktur kalimat. Kesepadanan struktur adalah keseimbangan antara gagasan dan unsur kalimat yang digunakan. Kejelasan subjek sebuah kalimat dapat dilakukan dengan cara menghindari penggunaan kata depan di, dalam, untuk, bagi, pada, sebagai, tentang, menurut, mengenai, dan sebagainya di depan subjek.

Contoh:

(1) Bagi semua mahasiswa Unimal harus membayar uang kuliah.

(2) Untuk mendapatkan data yang valid, peneliti harus ke lapangan.

Kalimat tersebut tidak efektif karena kalimat (1) tidak memiliki kesepadanan karena fungsi subjek tidak jelas. Kalimat di atas tidak menampilkan apa atau siapa yang harus membayar uang kuliah. Ketidakjelasan subjek disebabkan penggunaan kata depan bagi. Kalimat (2) tidak memiliki predikat. Kalimat di atas seharusnya ditulis seperti kalimat berikut

(1a) Semua mahasiswa Unimal harus membayar uang kuliah. (2a) Untuk mendapatkan data yang valid, peneliti harus pergi ke lapangan.

3) Ketepatan dalam kesejajaran Penggunaan Bentuk Kalimat

Santhi, Meita Sandra (2018:39) menyatakan bahwa bentuk-bentuk bahasa yang sejajar dalam sebuah kalimat memperlihatkan gagasan yang sejajar pula. Misalnya, jika bentuk kata pertama adalah nomina, maka bentuk kata kedua, ketiga, dan seterusnya juga harus menggunakan nomina. Kesejajaran antara gagasan dan bentuk bahasa yang dipakai dapat mempermudah pembaca untuk memahami makna kalimat.

Contoh:

(1) Tahap akhir penelitian ini adalah penyusunan laporan dan menyerahkan hasil penelitian.

(2) Jangan buang sampah di sini!

Pada kalimat (1) tidak menunjukkan kesejajaran bentuk, yaitu unsur penyusunan laporan dan menyerahkan hasil penelitian. Dengan demikian, kalimat di atas tidak memiliki kesejajaran atau keparalelan. Kalimat (2) juga tidak memiliki kesejajaran karena si penulis kalimat ingin menyatakan bahwa jangan buang sampah ke tempat tertentu. Akan tetapi, pada kenyataannya kalimat (2) bermakna bahwa jangan membuang sampah yang sudah ada di tempat tersebut. Supaya memperlihatkan kesejajaran, kedua kalimat tersebut dapat diperbaiki menjadi seperti kalimat berikut:

(1a) Tahap akhir penelitian ini adalah menyusun laporan dan menyerahkan hasil penelitian.

(1b) Tahap akhir penelitian ini adalah penyusunan laporan dan penyerahan hasil penelitian.

(2a) Jangan buang sampah ke sini!

4) Ketepatan Struktur Pengungkapan dan Makna Kalimat

Syahriandi (2019:147) menyatakan bahwa kepaduan kalimat adalah keeratan hubungan antara unsur-unsur yang membentuk kalimat tersebut. Ketidaktepatan hubungan dapat disebabkan oleh kesalahan penempatan kata atau penambahan kata yang seharusnya tidak diperlukan.

(1) Laporan ini saya harus perbaiki secepatnya.

(2) Kita telah bahas masalah tersebut dalam diskusi kita bulan lalu. 
Kalimat (1) dan (2) adalah kalimat pasif persona. Dalam kedua pasif tersebut, antara pelaku (persona) dan kata kerjanya (pasif) tidak boleh disisipkan unsur lain. Namun, dalam kedua kalimat tersebut terdapat harus dan telah antara persona dan pasif. Jadi, untuk menjaga kepaduan, keterangan modalitas harus pada kalimat (1), dan keterangan aspek telah pada kalimat (2) harus dipindahkan ke depan pelaku. Kedua kalimat tersebut, dapat diperbaiki menjadi sebagai berikut.

(1a) Laporan ini harus saya perbaiki secepatnya.

(2b) Telahkita bahas masalah tersebut dalam diskusi kita bulan lalu.

\section{Ketepatan Makna Kalimat}

Makna menjadi bagian penting yang harus diperhatikan dalam kalimat efektif. Makna yang tidak logis, multitafsir, berlebihan (kata) yang tidak jelas, dan tidak tegas menyebabkan sebuah kalimat menjadi tidak efektif. Syarat-syarat ketepatan makna kalimat adalah sebagai berikut:

1) Ketepatan Penalaran (Kelogisan)

Riana, Rati (2013:17) menyatakan Kelogisan dalam berbahasa berkaitan erat dengan penguasaan tata bahasa yang memadai dan penguasaan masalah yang ingin dikemukakan. Penyusunan yang kurang tepat dapat mengakibatkan nalar yang terkandung di dalamnya tidak runtut, sehingga kalimat yang dihasilkan kurang efektif.

Contoh:

(1) Akibat remnya blong, supir truk itu menabrak pohon kelapa.

Syahriandi dan Radhiah (2019:149) menyatakan bahwa kalimat di atas memiliki makna ganda dan ketidaklogisan, yaitu: (a) yang menabrak pohon adalah supir truk, bukan truk; dan (b) tidak mungkin supir memiliki rem. Pada kalimat tersebut, kata supir seharusnya dihilangkan saja, agar kata truk itu menjadi subjek.

(1a) Akibat remnya blong, truk itu menabrak pohon kelapa.

\section{2) Ketepatan Penggunaan Kata}

Ketepatan dalam kalimat efektif berhubungan dengan makna, kehematan penggunaan kata dan kelompok kata mensyaratkan bahwa informasi yang akan disampaikan dalam kalimat itu harus cermat dan tidak boros. Kehematan tidak berarti harus menghilangkan kata-kata yang dapat menambah kejelasan kalimat. Penghematan dilakukan terhadap kata yang memang tidak diperlukan, sejauh tidak menyalahi kaidah tata bahasa. Putrayasa (2010:30) menyatakan bahwa terdapat unsur-unsur tertentu yang merupakan bagian dari ungkapan idiomatik sebaiknya tidak dihilangkan. Ungkapan idiomatik yang unsur-unsurnya tidak boleh dihilangkan itu antara lain bergantung pada, terdiri atas, sesuai dengan, sejalan dengan, berkaitan dengan, dibandingkan dengan, serta sehubungan dengan.

3) Ketepatan dalam Kejelasan Pengungkapan

Putrayasa (2010:39) menyatakan bahwa bahasa ilmiah mensyaratkan ketunggalan arti, sehingga penulis harus mempertimbangkan setiap kata, kelompok kata, atau kalimat yang akan digunakan agar pembaca dapat memahami persis hal yang diungkapkan oleh penulis. Ketepatan dalam Ketegasan Pengungkapan

Syahriandi (2016:124) menyatakan bahwa selain kejelasan, ketegasan sebuah kalimat juga harus menjadi perhatian dalam penulisan karya ilmiah, sehingga kalimat yang dituliskan menjadi kalimat yang efektif. Kalimat efektif harus memberikan penegasan pada ide pokoknya sehingga ide pokoknya menonjol di dalam kalimat tersebut.

$\begin{array}{lll}\text { 4) Ketepatan dalam } & \text { Ketegasan } \\ \begin{array}{c}\text { Pengungkapan } \\ \text { Syahriandi }\end{array} & (2016: 124) & \text { menyatakan }\end{array}$ bahwa selain kejelasan, ketegasan sebuah kalimat juga harus menjadi perhatian dalam penulisan karya ilmiah, sehingga kalimat yang dituliskan menjadi kalimat yang efektif. Kalimat efektif harus memberikan penegasan pada ide pokoknya sehingga ide pokoknya menonjol di dalam kalimat tersebut. Berikut ini cara memberikan penegasan pada kalimat.

\section{METODE PENELITIAN}

Penelitian ini menggunakan pendekatan deskriptif dan jenis penelitian kualitatif. Moleong (dalam Zulmaliza, 2018:27) menyatakan bahwa data yang dikumpulkan dalam analisis deskriptif berupa kata-kata, gambar, dan bukan angka. Jenis Penelitian kualitatif merupakan penelitian yang menghasilkan deskripsi mengenai kata-kata lisan maupun tulisan. Arikunto (2017:22) menyatakan bahwa penelitian kualitatif yaitu 
penelitian objek yang berkembang apa adanya, tidak dimanipulasi oleh peneliti dan kehadiran peneliti tidak mempengaruhi dinamika pada objek tersebut. Jenis penelitian kualitatif menggunakan data alamiah sebagai sumber datanya, kemudian mengolah data tersebut dengan menggunakan metode deskriptif. Penggunaan pendekatan ini bertujuan untuk mendeskripsikan data selengkap-lengkapnya secara jelas dan lugas.

Data penelitian ini adalah kalimat tidak efektif yang terdapat dalam skripsi mahasiswa. Sumber data dalam penelitian ini adalah skripsi mahasiswa Prodi Pendidikan Universitas Malikussaleh yang dicetak pada tahun 2019, yaitu mencakup Prodi Pendidikan Bahasa Indonesia, Prodi Pendidikan Matematika, Prodi Pendidikan Fisika, dan Prodi Pendidikan Kimia, sedangkan Prodi Pendidikan Vokasional Teknik Mesin belum ada skripsi yang sudah tercetak pada tahun 2019. Keseluruhan skripsi yang sudah dicetak pada tahun 2019 adalah 83 skripsi. Dari jumlah skripsi tersebut, peneliti mengambil dua skripsi pada tiap-tiap prodi sebagai sumber data.

Teknik pengumpulan data yang digunakan dalam penelitian ini adalah teknik dokumentasi, teknik baca, dan teknik catat. Teknik ini dipilih untuk memperoleh data secara langsung dari objek penelitian. Sugiyono (2017:124) menyatakan bahwa teknik dokumentasi merupakan catatan dari suatu peristiwa yang sudah terjadi. Dokumen dapat berupa tulisan, gambar, atau karyakarya monumental dari seseorang. Dokumen dalam penelitian ini adalah skripsi mahasiswa Prodi Pendidikan Universitas Malikussaleh yang dicetak pada tahun 2019.

Teknik catat adalah cara yang dilakukan untuk mencatat data yang ada hubungan dengan penelitian. Mahsun (2012:93) menjelaskan bahwa teknik catat digunakan untuk mencatat data hasil penelitian. Peneliti menggunakan teknik catat bertujuan untuk mencatat data-data yang ada hubungannya dengan permasalahan penelitian, kemudian data-data tersebut diseleksi, diatur, dan diklasifikasikan berdasarkan rumusan masalah yang telah ditetapkan.

Teknik dokumentasi adalah pengumpulan dokumentasi, yaitu berupa skripsi mahasiswa Prodi Pendidikan Universitas Malikussaleh. Pengumpulan data (skripsi) dilakukan secara acak sehingga dipilih dua skripsi setiap prodi. Kemudian skripsi tersebut dibaca secara berulang-ulang dalam teknik baca. Teknik baca merupakan salah satu teknik pengumpulan data yang dilakukan untuk mendapatkan data penelitian. Setelah skripsi tersebut dibaca, kemudian dilanjutkan dengan teknik catat. Teknik catat dilakukan untuk mencatat kalimat-kalimat yang tidak efektif pada skripsi mahasiswa Prodi Pendidikan Universitas Malikussaleh ke dalam korpus data penelitian. Korpus data merupakan data yang dipakai sebagai sumber bahan penelitian.

Teknik analisis data dalam penelitian ini digunakan untuk menganalisis ketidakefektifan kalimat dalam skripsi mahasiswa Prodi Pendidikan Universitas Malikussaleh. Analisis data dilakukan setelah seluruh data terkumpulkan pada proses pengumpulan data. Mahsun (2012:253) mendefinisikan bahwa teknik analisis data adalah upaya yang dilakukan untuk mengelompokkan data. Analisis data dilakukan dengan mengorganisasikan data, menjabarkan kedalam unit-unit, melakukan sintesa, menyusun kedalam pola, memilih mana yang penting dan yang akan dipelajari, dan membuat kesimpulan yang dapat diceritakan kepada orang lain.

\section{HASIL PENELITIAN}

Berdasarkan hasil penelitian dari 8 skripsi Prodi Pendidikan Universitas Malikussaleh, ditemukan 339 kalimat tidak efektif. Ketidakefektifan kalimat tersebut adalah sebagai berikut.

\section{Kekeliruan Bentukan Bagian Kalimat}

Kalimat tidak efektif yang disebabkan oleh kekeliruan bentukan bagian kalimat terdapat 124 kalimat. Kesalahan bentukan bagian kalimat tersebut terjadi karena penggunaan tanda baca yang tidak tepat. Umumnya, kesalahan bagian kalimat tersebut terjadi karena menggunakan kata keterangan pada awal kalimat. Penggunaan kata keterangan di awal kalimat menyebabkan terjadinya bentukan bagian kalimat yang tidak jelas sehingga kalimat tersebut dikategorikan ke dalam kalimat tidak efektif. Kalimat tersebut dapat diperbaiki dengan menambahkan tanda koma setelah keterangan. Menurut teori, 
tanda koma dapat digunakan di bagian belakang keterangan yang terletak pada awal kalimat.

Kesalahan bagian kalimat juga terjadi karena tidak adanya penggunaan tanda baca koma sebelum konjungsi pertentangan sedangkan dan akan tetapi. Berdasarkan teori, konjungsi intrakalimat sedangkan dan akan tetapi biasa didahului oleh tanda koma. Kalimat tersebut dapat diperbaiki dengan menambahkan tanda baca koma sebelum konjungsi sedangkan dan akan tetapi.

\section{Kesalahan penggunaan unsur dan fungsi kalimat}

Kalimat tidak efektif yang disebabkan oleh kesalahan penggunaan unsur dan fungsi kalimat terdapat 59 kalimat. Kesalahan tersebut meliputi kesalahan subjek dan predikat yang tidak jelas sehingga kalimat tersebut tidak efektif. Umumnya, ketidakefektifan kalimat yang disebabkan karena kesalahan unsur dan fungsi kalimat dikarenakan ketidakjelasan fungsi kalimat.

Ketidakjelasan fungsi predikat biasnanya dikarekan penggunaan kata yaitu sebagai penanda predikat. Padahal, kata yaitu bukanlah penanda predikat, sehingga kalimat tersebut tidak memiliki unsur predikat yang jelas. Kalimat tersebut dapat diperbaiki dengan menggantikan kata yaitu dengan kata penanda predikat adalah. Sementara itu, ketidakjelasan fungsi subjek disebabkan oleh penggunaan kata keterangan sebelum fungsi subjek sehingga fungsi subjek menjadi tidak jelas.

\section{Kesalahan Kesejajaran Unsur dan Makna Kalimat}

Kalimat tidak efektif yang disebabkan oleh kesalahan kesejajaran unsur dan makna kalimat terdapat sebanyak 5 kalimat. Kesalahan tersebut terjadi karena tidak memiliki kesejajaran unsur dalam kalimatnya. Kesejajaran bentuk kalimat menggambarkan pikiran dan gagasan yang sejajar. Kesejajaran pikiran dan gagasan bentuk bahasa yang dipakai dapat mempermudah pembaca untuk memahami makna kalimat. Kesalahan kesejajaran kalimat yang didapatkan dalam penelitian ini antara lain; pengembangan, mendorong, memfasilitasi, dan meningkatkan. Kalimat tersebut dapat diperbaiki dengan mengubah kata pengembangan menjadi kata mengembangkan sehingga kalimat tersebut memiliki kesejajaran gagasan.

\section{Kesalahan Struktur Pengungkapan dan Kepaduan Kalimat}

Kalimat tidak efektif yag disebabkan oleh kesalahan struktur pengungkapan dan kepaduan kalimat terdapat sebanyak 49 kalimat. Kesalahan tersebut terjadi karena penggunaan konjungsi yang berlebihan dan ketidakjelasan struktur pengungkapan. Kesalahan struktur kalimat disebabkan oleh penggunaan konjungsi yang berlebihan dan tidak tepat.

\section{Kesalahan Penggunaan Kata}

Kalimat tidak efektif yang disebabkan oleh kesalahan penggunaan kata dalam penelitian ini terdapat sebanyak 94 kalimat. Kesalahan penggunaan kata meliputi pemborosan kata, penggunaan bahasa yang tidak tepat, dan penggunaan kata yang bermakna ambigu.

\section{Kesalahan Kejelasan Pengungkapan}

Kalimat tidak efektif yang disebabkan oleh kesalahan kejelasan pengungkapan dalam penelitian ini terdapat sebanyak 44 kalimat. Kesalahan kejelasan pengungkapan dalam penelitian ini meliputi penggunaan kata tanya yang tidak tepat. $\begin{array}{rrr}\text { Ketidakefektifan } & \text { kalimat } & \text { tersebut } \\ \text { karena menggunakan } & \text { frasa } & \text { tanya. } \\ \text { Penggunaan frasa } & \text { tanya } & \text { dapat }\end{array}$ membingungkan pembaca sehingga menyebabkan terjadinya kesalahan penafsiran Kalimat tersebut dapat diperbaiki dengan menghilangkan frasa tanya dan mengganti dengan kata yang tepat supaya kalimatnya menjadi jelas.

\section{Kesalahan Ketegasan Pengungkapan}

Kalimat tidak efektif yang disebabkan oleh kesalahan ketegasan pengungkapan dalam penelitian ini terdapat sebanyak 3 kalimat. Kesalahan tersebut disebabkan oleh pengunaan kata kunci kalimat yang tidak tepat sehingga kalimat tersebut tidak memiliki ketegasan pengungkapan. Ketegasan sebuah kalimat juga harus menjadi perhatian dalam penulisan kalimat. Kalimat efektif harus memberikan penegasan terhadap ide pokoknya sehingga ide pokoknya menonjol di dalam kalimat tersebut. 


\section{PENUTUP}

Berdasarkan hasil penelitian dari 8 skripsi mahasiswa Prodi Pendidikan Universitas Malikussaleh, dapat disimpulkan bahwa jumlah kalimat tidak efektif yang terdapat dalam skripsi mahasiswa Prodi Pendidikan Universitas Malikussaleh yang lulus pada tahun 2019 adalah 339 kalimat. Berikut ini akan dijabarkan pengklasifikasian kesalahan kalimat tersebut.

a) Kalimat tidak efektif yang disebabkan oleh kekeliruan bentukan bagian kalimat terdapat 124 kalimat. Kesalahan bentukan bagian kalimat tersebut terjadi karena penggunaan tanda baca yang tidak tepat.

b) Kalimat tidak efektif yang disebabkan oleh kesalahan penggunaan unsur dan fungsi kalimat terdapat 59 kalimat. Kesalahan tersebut meliputi kesalahan subjek dan predikat yang tidak jelas sehingga kalimat tersebut tidak efektif.

c) Kalimat tidak efektif yang disebabkan oleh kesalahan kesejajaran unsur dan makna kalimat terdapat sebanyak 5 kalimat. Kesalahan tersebut terjadi karena tidak memiliki kesejajaran unsur dalam kalimatnya.

d) Kalimat tidak efektif yag disebabkan oleh kesalahan struktur pengungkapan dan kepaduan kalimat terdapat sebanyak 49 kalimat. Kesalahan tersebut terjadi karena penggunaan konjungsi yang berlebihan.

e) Kalimat tidak efektif yang disebabkan oleh kesalahan penggunaan kata dalam penelitian ini terdapat sebanyak 94 kalimat. Kesalahan penggunaan kata meliputi pemborosan kata, penggunaan bahasa yang tidak tepat, dan penggunaan kata yang bermakna ambigu.

f) Kalimat tidak efektif yang disebabkan oleh kesalahan kejelasan pengungkapan dalam penelitian ini terdapat sebanyak 44 kalimat. Kesalahan kejelasan pengungkapan dalam penelitian ini meliputi penggunaan kata tanya yang tidak tepat.

g) Kalimat tidak efektif yang disebabkan oleh kesalahan ketegasan pengungkapan dalam penelitian ini terdapat sebanyak 3 kalimat. Kesalahan tersebut disebabkan oleh pengunaan kata kunci kalimat yang tidak tepat sehingga kalimat tersebut tidak memiliki ketegasan pengungkapan.

\section{DAFTAR PUSTAKA}

Arikunto, Suharsimi. 2017. Pengembangan Instrumen Penelitian dan Penilaian Program. Jakarta: Rineka Cipta.

Febriantika, Reza. 2016. "Keefektifan Kalimat Pada Tajuk Rencana Surat Kabar Harian Lampung Post Edisi Maret 2015 dan Implikasinya Pada Pembelajaran Bahasa Indonesia di SMK". Skripsi. Lampung: Universitas Lampung.

Jehamin, Emilinda Oktaviani. 2019. "Analisis Ketidakefektifan Peggunaan Kalimat Pada Abstrak Skripsi Mahasiswa Program Studi Pendidikan Sejarah Universitas Sanata Dharma Lulusan Tahun 2017". Skripsi, Yogyakarta:Universitas Sanata Dharma.

Kusmiyati, Indri. 2016. "Penggunaan Kalimat Efektif Pada Soal Latihan dalam Buku Paket Bahasa Indonesia SMP Kelas VII Karya Mariati Nugroho dan Sutopo". Skripsi. Surakarta: Universitas Muhammadiyah Surakarta.

Mahsun. 2012. Metode Penelitian Bahasa. Jakarta: Raja Grafindo Persada.

Parto. 2018. "Kalimat Efektif dan Pengajarannya di SMP/MTs Pada Era Global". Jember: PS PBSI FKIP Jember

Putrayasa, Ida Bagus. 2010 Kalimat Efektif: Diksi Struktur, dan Logika Edisi Revisi. Bandung: Revika Aditama.

Sasangka, Sry Satriya Tjatur Wisnu. 2014. Seri Penyuluhan Bahasa Indonesia Kalimat. Jakarta: Pusat Pembinaan dan Pemasyarakatan Badan Pengembangan dan Pembinaan Kementerian Pendidikan dan Kebudayaan. 
Riana, Rati. 2013. Ketidakefektifan Kalimat Pada Penulisan Skripsi. Semarang: Semarang University Press.

Syahriandi. 2016. Sintaksis Bahasa Indonesia. Aceh Utara: FKIP Unimal.

Syahriandi. 2018. Sintaksis Bahasa Indonesia Pemahaman Objek Kajian. Lhokseumawe:. Seva Bumi Persada.

Syahriandi dan Radhiah. 2019. Terampil Menulis Ilmiah.Lhokseumawe: Seva Bumi Persada.

Sugiyono. 2017. Metode Penelitian Kualitatif. Bandung: Alfabeta

Zulmaliza, Septia Nita. 2018. "Analisis Keefektifan Kalimat Pada Skripsi Mahasiswa Program Studi Pendidikan Matematika Unsyiah". Skripsi. Banda Aceh: Universitas Syiah Kuala. 